\title{
Toward a "Masonic musicology" Some theoretical issues on the study of Music in relation to Freemasonry
}

\author{
Hacia una "musicología masónica" \\ Algunas cuestiones teóricas sobre el estudio de la música en relación \\ con la masonería
}

\author{
David Vergauwen \\ Universidad Libre de Bruselas, Bélgica \\ davidvergauwen@yahoo.com
}

Recepción: 30 de noviembre de 2018/Aceptación: 15 de diciembre de 2018.

doi: https://doi.org/10.15517/rehmlac.v10i2.34940

Keywords

Ritual; Freemasonry; Music Theory; Ethnomusicology; Masonic Musicology.

Palabras clave

ritual; masonería; teoría de la música; etnomusicología; musicología masónica.

Abstract

The paradigm called 'New Historicism' and its many spin-offs like 'New Musicology', proclaims that an art historian should no longer limit itself to solely the study of an artwork, but should instead focus on its historical and sociological "context". By means of a new tool that we shall label "Masonic musicology" will argue that the logic used by New Musicologists and of even Ethnomusicologists also applies to the study of music in relation to freemasonry. Studying a composer's involvement with freemasonry, can lead to inspiring new interpretations of a composer's work. The goal of this article is threefold; first, it determines some interesting findings other scholars have put forward. Secondly, it is a theoretical framework for the undertaking of similar studies. Thirdly, it relates this theoretical framework to other up-to-date paradigms, to thus encourage scholars not to treat the masonic connection in art as the taboo subject it sometimes is.

\section{Resumen}

El paradigma llamado "nuevo historicismo" y sus muchas ramificaciones como "nueva musicología", proclama que ya no se debería de limitar el estudio a la obra de arte en sí misma, sino centrarse en el "contexto" de su historia y sociología. Mediante una nueva herramienta que llamaremos "musicología masónica". Se argumenta que la lógica utilizada por los nuevos musicólogos, incluso los etnomusicólogos, también puede aplicarse al estudio de la música en relación con la masonería. El estudio de la participación de un compositor en la masonería puede conllevar nuevas interpretaciones de la música de dicho compositor. El objetivo de este artículo es triple; primero, presenta algunos hallazgos interesantes sobre este tema; en segundo lugar, ofrecer un marco teórico para estudios similares; y en tercer lugar, conecta este marco teórico con otros paradigmas actualizados para que ya no sea tabú tratar la conexión del arte con la masonería. 


\section{Introduction}

Any scholar interested in music in relation to the masonic phenomenon will easily perceive the divide between two competing methodologies. On the one hand, there are studies that emphasize the context of a piece of music, whereby cultural, economical and political backgrounds are worked into an analysis to provide a clear picture of what it was that made the piece relevant. On the other hand, there is a tendency to insist on essentialism, which roughly explains music as a closed narrative, made up by notes, keys, formulas, stylistic elements, instrumental colouration, etc. and freemasonry as an even more closed circuit of codes, symbols, rituals an iconography. Therefore, music in relation to freemasonry, is discussed in terms of keys having a certain hidden masonic meaning, masonic symbols that can be translated into notes and musical formulas that can be said to represent anything within a masonic context, if properly argued. Even worse is the wellknown and among some people beloved number game, where bar numbers, strong beats or any other musical feature is counted, analysed and forced into an overall narrative in which the author will equate certain meanings with numbers, thereby lending his or her analysis an aura of scientific objectivity; it all adds up - the numbers don't lie.

We have become accustomed to perceiving the latter method as a thing of the past. And yet, if we consider some of the numerological oddities that have been written in the past about Mozart's 'Die Zauberflöte', one can be amazed by the extent by which this kind of thinking infiltrated the way scholars still talk and write on the subject ${ }^{1}$. H.C. Robbins Landon is amongst Mozart scholars hardly a nobody. Yet, he too went on quoting masonic numerology, incorporating it in his own description of higher degrees that Mozart or his circle probably never knew. He then went on to point out these numbers in the score of 'Die Zauberflöte $^{2}$. This was then subsequently taken up by other authors quoting Robbins Landon as an authority. Tjeu Van den Berk in his book on the same opera claims the number eighteen as particularly significant and although he makes some jokes on the expense of earlier numerologists (including Robbins Landon), in the end, his own analyses relies heavily on precisely this material ${ }^{3}$. Such claims have not yet ceased to make an impact, even on the most serious of scholars. The $3^{\text {rd }}$ International Conference on the History of Freemasonry in may 2011 welcomed a paper about Mozart's last symphony as a contrapuntal temple in which images of temples and spiral staircases were said to have been

\footnotetext{
${ }^{1}$ Johannes Duda, Gunther Kerner and Dieter Dalchow, W.A. Mozart-Die Dokumentation seines Todes (Pähl/Obb: von Bebenburg, 1966).

${ }^{2}$ H.C. Robbins-Landon, 1791: Mozart's Last Year (New York: Thames and Hudson, 1988), 127-132.

${ }^{3}$ M.F.M. Van Den Berk, The Magic Flute: Die Zauberflöte: An Alchemical Allegory (Leiden: Brill, 2004). There is a separate section in the book discussing the number 18 .
} 
worked into the music ${ }^{4}$. It is quite clear that unless these authors can produce clear empirical evidence that the numbers and correlations they present were premeditated or thought to be of significance by contemporary commentators, their claims must be conceived to be tenuous at best.

A scholar wanting to address the issue of music in relation to freemasonry, has roughly two choices. He can either focus on his intend to discover the "hidden meaning" behind a composer's score and interpret that meaning in terms of his masonic affiliations, or he can try to find a way to explain why that piece had a particular masonic association by looking at its historical context. This article will argue that only the latter has a good chance of integrating the study of masonic music within current academic tendencies within disciplines like musicology or history. We will label this way of thinking "masonic musicology", which must be understood as a methodology that helps the scholar to deal with the particular problems and pitfalls of studying music in relation to freemasonry. In this article we will present examples of noteworthy studies that were inspirational in our own research on Belgian masonic music ${ }^{5}$.

Two things should be clear from the start. First of all, I am not saying that solid studies on music and freemasonry are things of the recent past. That would be needlessly underestimating many early studies in this field that are still valuable today. I am merely suggesting that in order to keep up with contemporary scholarly practice, musicologists studying freemasonry should seek to make their contributions relevant to other disciplines. They can do so by leaving behind the old practice of "revealing" hidden symbolic meanings in scores and finding their inspiration elsewhere. If anything, this article is an appeal to musicologists wanting to study freemasonry to seek inspiration in other fields, such as ethnomusicology or cultural anthropology. Some older studies already did just that, even if the majority didn' $t^{6}$. Second of all, although the term "masonic musicology" might be new, the practice it describes is not. Indeed, this article will quote many examplary studies of music within the context of freemasonry, none of them wielding the term "masonic musicology". I am simply bringing these studies together to uncover their common denominator, while trying at the same time to highlight where and why these studies were relevant contributions to other scholars, sometimes working on totally different topics. It is precisely the question of how and when the study of masonic music could be relevant in our understanding of the history of music or the history of freemasonry in general, that concerns us.

\footnotetext{
${ }^{4}$ Neva Krysteva, "Mozart: The contrapuntal temple in the last symphony" (Paper presented in the $3^{\text {rd }}$ International Conference on the History of Freemasonry, The George Washington Masonic National Memorial, Alexandria, Virginia, 27-29 may, 2011).

5 David Vergauwen, Kolommen van Harmonie. Muziek en Vrijmetselarij in het Brussel van de Negentiende Eeuw (Brussel: ASP, 2015), 193-207.

${ }^{6}$ A good example is the often-quoted study of Nettle on Mozart's masonic music: Paul Nettle, Mozart and Masonry (New York: Philosophical Library, 1957).
} 


\section{What is 'Masonic musicology'?}

The academical research into the history of freemasonry has only recently - since little more than two decades or so - caught up with the cutting edge of mainstream contemporary historical scholarship. This kind of research has evolved from dull in-depth 'histories' of particular masonic lodges into a full-fledged research into the social, religious, political and artistic position of the masonic phenomenon in its historical context. However, the history of freemasonry is still a field that is very much "under construction". It is still seeking to define itself, still in the process of uncovering its own methods, source materials and research terrain. Because this field is by nature cross-disciplinary, scholars of other disciplines, such as philosophy, history, sociology, religious studies and anthropology, have happily joined in. All these scholars having only one thing in common: an interest in the history of freemasonry.

This interest can be attributed to the many new tools Post Modernism has provided us. Only a few decades ago, scholars might have considered studying anything in relation to freemasonry as too speculative, too arbitrary, too shaky. It might even have caused problems for some scholars to associate themselves with the field of masonic history, since a study of eighteenth-century masonic music might have implied that the scholar in question was somehow associated with or even supportive of freemasonry today. Even worse: he might himself be a freemason. In the last few decades a tolerance amongst academics has emerged that permits a serious scholar to venture into this previously unspeakable terrain to pursue lines of inquiry earlier generations would have regarded as professional suicide.

So, with the interest in the history of freemasonry blosseming and the academic field opening up to new lines of thought, it is not surprising that art historians too, started to take an interest in the history of freemasonry. After all architecture is a dominant theme within freemasonry, making it important for art historians to study the architecture of houses, temples, gardens and other various building features within the context of freemasonry ${ }^{7}$. Unfortunately less persistent were the attempts to enter music into the equation. Taking into account all studies concerning music and freemasonry, and eliminating all Mozart-related contributions, one is left only with a very diverse collection of studies making all sorts of points, using all sorts of methods, resulting in all sorts of

\footnotetext{
7 Freemasonry and architecture: James Stevens Curl, The Art \& Architecture of Freemasonry (New York, 1999). Freemasonry and art: Christophe Loir and Jacques Lemaire, Franc-Maçonnerie et Beaux-Arts (Bruxelles: 2007); Helmut Reinalter, Freimaurerische Kunst - Kunst der Freimaurerei (Innsbruck: 2005); Jeffrey Tyssens ed., Schatten Van De Tempel (Mercatorfonds, 2006). Freemasonry and Garden Architecture: Alf Hermann, Geheimes_Louisenlund. Einblicke in Europa's Bedeutendsten Freimaurerpark (Kiel, 2010); Jan Snoek, Monika Scholl \& Andréa Kroon eds., Symbolik in Gärten des 18. Jahrhunderts. Der Einfluss unterschiedlicher philosophischer Strömungen, wie auch der Freimaurerei (Den Haag, 2006); Franz Wegener, Der Freimaurergarten (Norderstedt, 2008). Freemasonry and film: Jean-Louis Coy, Forces Occultes. Le complet judéo-maçonnique au cinéma (Paris, 2008).
} 
quality. In our attempt to introduce the tool called Masonic musicology, we will try to offer an insight into the research possibilities for any kind of research of music in relation to freemasonry.

When Art historians in the early eighties refused to make an a priori distinction between a cultural product and the times in which it was produced, a new methodology called New Historicism was coined. ${ }^{8}$ At first the movement consisted of a group of literary scholars, specialized in Elizabethan and Jacobean Renaissance Literature ${ }^{9}$. During the nineteens the movement spread its wings and it was soon taken up in other fields. In 1992 Jean Howard famously wrote that the past "is not simply 'found' in archives", but is a construct made up of textualized traces assembled in various configurations by the historian/interpreter ${ }^{10}$. The individuals the historian studies could not escape the urge to try and make sense of the world around them. This means they were constantly relating their own personal experiences to other economic, political, religious, artistic, etc. experiences. In making sense of the world, every individual makes an infinite amount of connections between his own experiences and the world around him. This is what Stephen Greenblatt labelled the circulation of social energy ${ }^{11}$.

To offer a concrete example of this circulation of social energy, we might consider Richard Wagner's last work, Parsifal, first produced in Bayreuth in 1882. This is a bühnenweihfestspiel as Wagner himself famously called it, about a young man, in search of his humanity, who after many trails ends up being initiated into an all-male crypto-monastic brotherhood of the Grail. Now imagine you are a nineteenth-century freemason, trying to make sense of this work and its music. Is it so hard to imagine that your own experience with masonic initiation rites colours your view, your interpretation, your 'making sense' of Parsifal? Or the other way around: does a work like Parsifal influence a non-mason's idea of the masonic ritual? One does not need Wagner to be a freemason (he wasn't!) in order to accept that his Parsifal was such a success amongst freemasons, because of their own experiences with ritual practices. Such was the case in Brussels, where the first Belgian Wagner Society was founded as early as 1872 and continued to thrive within an elite circle of haut-bourgeois liberals, many of whom were freemasons. Wagner's music continued to be played at masonic meetings up until the First World War ${ }^{12}$.

So far for New Historicism. At the end of the nineties its musicological spin-off, called New Musicology, was established within the scientific community. In 2000 Susan McClary officially declared "war" on every "purely musical" interpretation of music. Her

\footnotetext{
${ }^{8}$ Stephen Greenblatt ed., "The Forms of Power and the Power of Forms in the Renaissance", Genre 15 (1982): 5.

${ }^{9}$ Jürgen Pieters, Moments of Negotiation. The New Historicism of Stephen Greenblatt (Amsterdam, 2001), 25.

10 Jean Howard, "The New Historicism in Renaissance Studies", inNew Historicism and Renaissance Drama, : Richard Wilson \& Richard Dutton eds. (London/New York, 1992), 19-32.

${ }^{11}$ Stephen Greenblatt, Shakespearean Negotiations: The Circulation of Social Energy in Renaissance England (Berkeley, 1988), introduction.

12 Vergauwen, "Wagner und die Freimaurer - Die Wagner-Mode in Brüssel (1870-1900)", Wagnerspectrum 2 (2012): 201-210.
} 
work, and that of her fellow New Musicologists, was a quest for cultural interpretations of Western art music ${ }^{13}$. New Musicologists try to establish the conditions for the production and reception of artworks, looking for the elements that allowed cultural activities to "make sense" in the eyes of their contemporaries. This was of course nothing very new. Taking their cue from Greenblatt's New Historicism, New Musicologists established a paradigm that would explore in music history the kinds of processes Raymond Williams calls "structures of feeling", Frederic Jameson the "political unconscious", Roland Barthes "mythodologies", Thomas Kuhn "paradigms", Kaja Silverman "dominant fictions" or Ross Chambers "social contracts"14.

So musicologists started to search for the 'social knowledge' (mythologies, symbols, conventions, etc.) an audience must have had when they tried to make sense of an artistic product. In doing so, they are turning their backs on the traditional method of hermeneutics that focuses on explicating deliberate meanings. Now according to New Historicism there is no one master-narrative, no monolithic explanation of events. To quote Greenblatt himself: "It is important to resist the temptation to reduce all cultural phenomena into a single master discourse"15. A single song can be interpreted in multiple ways, can be put against so many backgrounds, that one can say that the background, the narrative and ultimately the meaning of a song cannot exist ${ }^{16}$. This leads McClary to rigorously declare that music "is assembled of heterogeneous elements that lead away from the autonomy of the work to intersect with endless chains of other pieces, multiple - even contradictory - cultural codes, various moments of reception, and so on. If music can be said to be meaningful, it cannot be reduced to a single, totalized, stable meaning ${ }^{17}$.

This interpretive freedom made it possible for other academic fields to develop their own brand of historicism, art history or musicology. To offer new perspective on old materials, even the principles of ethnomusicology began to be applied to the canon of Western classical music ${ }^{18}$. Now here is a field of expertise that can be of remarkable significance to the study of masonic music. If you think about it, the interests of an ethnomusicologist do not differ that much from those of a musicologists of freemasonry. They both study a particular 'tribe' with its own unique culture, its own habitat and

\footnotetext{
${ }^{13}$ Susan McClary, Conventional Wisdom. The Content of Musical Form (Berkeley/London, 2000), 1-2.

${ }^{14}$ Again refering to: Susan McClary, "Conventional Wisdom", 4-5; and also: Raymond Williams, Marxism and Literature (Oxford, 1977); Fredric Jameson, The Political Unconscious: Narrative as a Socially Symbolic Act (Ithaca, 1981); Roland Barthes, Mythologies trans. A. Lavers (New York, 1972); Thomas S. Kuhn, The Structure of Scientific Revoutions (Chicago, 1962); Kaja Silverman, "The Dominant Fictions", in Male Subjectivity at the Margins, ed. Kaja Silverman (New York, 1992); Ross Chambers, Story and Situation: Narrative Seduction and the Power of Fiction (Minneapolis, 1984).

${ }^{15}$ Greenblatt, Shakespearean Negotiations, 3.

${ }^{16}$ Greenblatt, "The Forms of Power", 5.

${ }^{17}$ McClary, "Conventional Wisdom", 7.

18 Bruno Nettl, "Mozart and the Ethnomusicological Study of Western Culture: An Essay in Four Movements", in Desciplining Music: Musicology and its Canon, Katherine Bergeron \& Philip V. Bohlman eds. (Chicago, 1992), $137-155$.
} 
habitus. They both try to figure out what music means to them and how they employ it. Getting an 'inside understanding' is important to both of them.

One concrete and noteworthy area of research where ethnomusicology might be considered of crucial importance, is the study of rituals and the role of music therein. The performance of rituals strikes at the very core of masonic activity. Many noteworthy scholars like Jan Snoek and Henrik Bogdan have rightfully devoted numerous well documented contributions on the subject ${ }^{19}$. Some scholars trying to make sense of the masonic rituals they are studying, have tried to find inspiration in the works of cultural anthropologists like Clifford Geertz and Victor Turner. Geertz was an anthropologist whose field work included the study of social interactions within well-defined communities. This led to his magnum opus 'The Interpretation of Cultures', published in $1973^{20}$. Geertz himself described his aim as 'the study of other peoples' cultures (...) involves discovering who they think they are, what they think they are doing and to what end they think they are

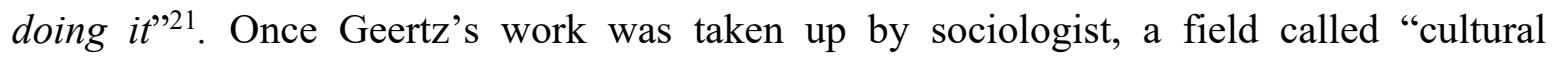
sociology" was born, in which the principles applied by anthropologists in their study of the behaviour of other cultures, could be used in the sociological study of the many subcultures within western society ${ }^{22}$. The work of Jeffrey Alexander in particular analyses many of the social and political practices we have come to know today in terms of 'rituals' or 'performances'23. It is therefore not hard to understand why historians of freemasonry tend to be interested in the work of Clifford Geertz and his fellow cultural anthropologists. In his work on a particular ritual, known as a 'lodge of sorrow' in Belgium, Jeffrey Tyssens understandably referred to cultural anthropology with Geertz and Turner as an inspiration for his own study ${ }^{24}$.

If it has become established practice to employ methods thought up by cultural anthropologists to the study of masonic rituals, does it not stand to reason that a musicologist interested in masonic music might find inspiration in the methods of ethnomusicologists ${ }^{25}$. After all, the practice of studying music in relation to ritual practices

\footnotetext{
${ }^{19}$ Henrik Bogdan, Western Esotericism and Rituals of Initiation (New York, 2007); Bogdan. "The Sociology of the Construct of Tradition and Import of Legitimacy in Freemasonry", in Constructing Tradition: Means and Myths of Transmission in Western Esotericism, Andreas Kilcher ed. (Leiden/Boston: Brill, 2010), 217-238; Snoek, Initiations. A methodological approach to the Application of Classification and Definition Theory in the Study of Rituals (Pijnacker, 1987); Snoek, Initiating Women in Freemasonry: The Adoption Rite (Leiden: Brill, 2011); Jens Kreinath, Snoek \& Michael Stausberg, Theorizing Rituals: Issues, Topics, Approaches, Concepts (Leiden/Boston: Brill, 2007).

${ }^{20}$ Clifford Geertz, The Interpretation of Cultures (New York, 1973).

${ }^{21}$ Geertz, "Passage and Accident: A Life of Learning", in Available Lights: Anthropological Reflections on Philosophical Topics (Princeton, 2000), 16.

22 Jeffrey Alexander \& Philip Smith, "Introduction: The Rise and Fall an Rise of Clifford Geertz", Interpreting Clifford Geertz. Cultural Investigation in the Social Sciences, eds. Alexander, Smith \& Matthew Norton (New York, 2011), 1-8.

${ }^{23}$ Alexander ed., The Meaning of Social Life: A Cultural Sociology (Oxford: Oxford University Press, 2003) and "Cultural Pragmatics: Social Performance between Ritual and Strategy", Sociological Theory 22, no. 4 (2004): $527-573$.

${ }^{24}$ Tyssens, In Vrijheid Verbonden. Studies over Belgische Vrijmetselaars en hun Maatschappijproject in de 19de eeuw (Gent, 2009), 161-200.

25 Jaap Kunst, Musicologica: A Study of the Nature of Ethnomusicology, Its Problems, Methods and Representative Personalities (Amsterdam, 1950).
} 
within that discipline is already decades old and many individual studies have pointed out how music can play an important (and even crucial) part during a ritual ${ }^{26}$. It would never occur to an ethnomusicologist to study the music without the ritual. It is however standard practice for historians of freemasonry to study the ritual without the music. The music of a masonic ritual is often regarded as mere decoration and very few historians will stop to consider that music might not only dictate the natural 'flow' of the ritual, but that it might also 'perform' in the sense that the music does not illustrate the ritual, it is a part of it.

A good case in point is the Belgian lodge of Sorrow, given in Brussels on 10 February 1866. It is one of the rituals studied by Jeffrey Tyssens ${ }^{27}$. He could not have studied the cantate written especially for this occasion, since it was thought to be irretrievably lost. It was not until the rather recent recovery of the composer's autograph in the collection of the Royal Music Conservatory in Brussels that further research was made possible ${ }^{28}$. With the score published and performed, it was possible to study the place and the purpose of the music in this ritual. One of the most striking features of this two-part cantate was that the first part effectively voiced the sorrow of the attending freemasons by the loss of their departed king. The end of this first part is an actual prayer in which the bass singer asks the freemasons the stand, before he leads them in prayer asking Jehovah to admit the soul of the dead king to paradise. It is interesting to note that at that point in the ritual, the music is not illustrating anything, it is trying to actually achieve something: the attending masons are trying to sing the deceased ruler into heaven. This is an act that has many parallels in other cultures, like the Thai Mon, who play the Phleg Prachum Phloeng when the body is given over the flames, in order to sing the deceased to eternity. In the second part of the cantates, however, the masons take a more relaxed attitude, where they are invited to witness a small play acted out in which the soul of the dead king enters into a dialogue with Jehovah himself. Here the freemasons will find out whether their actions in the first part can be deemed successful and the outcome of this little drama is later commented upon.

So here we have a clear distinction between the more passive attitude in the second part of the cantate and the more active role they have in the first. In the first part the masons are asked to perform part of their ritual by singing, while in the second part they are simply expected to sit back and wait for the outcome of their actions. In anthropological terms, the

\footnotetext{
${ }^{26}$ For example: Deborah Wong, "Mon Music for Thai Deaths: Ethnicity and Status in Thai Urban Funerals", in Asian Folklore Studies 57, no. 1 (1998): 99-130; Joseph C. Hermanowicz \& Harriet P. Morgan, "Ritualizing the Routine: Collective Identity Affirmation", Sociological Forum 14, no. 2 (1999): 197-214. Jan Houben, "The Ritual Pragmatics of a Vedic Hymn: The «Riddle Hymn» and the Pravargya Ritual”, Journal of the American Oriental Society 120, no. 4 (2000): 499-536; Dana Rappopor, "Ritual Music and Christianization in the Toraja Highlands, Sulawesi", Ethnomusicology 48 (2004): 378-404 and many more.

27 Tyssens, “A Lodge of Sorrow for King Leopold I of Belgium (1866): Masonic Patriotism and Spirituality on Trial”, Journal for Research into Freemasonry and Fraternalism 3, no. 2 (2012): 248-264.

${ }^{28}$ Vergauwen, “'Aux Mânes d'un F[rère] qui fut Roi': a Cantata by K.L. Hanssens On the Death of King Leopold I of the Belgians", Journal for Research into Freemasonry and Fraternalism 3, no. 2 (2012): 265-287.
} 
music of this ritual teaches us what those freemasons thought they could do to participate in the spiritual transfiguration of their deceased figure head. This is exactly what masonic musicology should be all about: making sense of freemasonry by means of the music they use.

While ethnomusicology might be a great inspiration when dealing with the music that accompanies masonic rituals, masonic musicology is a much broader term that draws inspiration from all kinds of ways in which we have come accustomed to study music. Composers who are freemasons, for example, are often very conscious of the philosophical choices they make. This might in turn colour their political and social views. One brand of musicology that is very focused on the way a composer's identity can find its way to his or her music, is "queer musicology". In 1990 queer musicology arrived at a conference of the American Musicological Society, which resulted, in 1994, in the first edition of The New Gay and Lesbian Musicology by Philip Brett, Elizabeth Wood and Gary C. Thomas ${ }^{29}$. There are indeed some similarities between these queer musicologists and any musicologist who wants to study music in relation to freemasonry. Just like the New Gay and Lesbian Musicologist the masonic musicologist needs to be sensitive about the philosophical and cultural choices 'his' musicians made (make) in life.

For instance, if Philip Brett argues that it is up to the New Gay and Lesbian Musicologist to a) discover new facts (Was Schubert gay?) and b) study themes as homophobia and homosexuality in relation to musical analyses, then it must be said that the task of the Masonic Musicologist is not at all that different. He also needs to a) discover new facts (Was Beethoven a freemason?) and b) study masonic themes in relation to musical analyses (including anti-masonry). In that way, masonic musicology can be understood as a spin-off of New musicology. It is a tool especially sharpened to tackle the sometimes unique problems of dealing with music that is in any way associated with freemasonry. Let's now turn away from the theoretical issue to tackle the objectives of this methodology, by way of a couple of examples.

\section{What is the objective of 'Masonic musicology'?}

The object of Masonic musicology must be twofold. In the strict sense it involves either the discovery of new historical facts and data or new and revealing interpretations of those facts. Extensive research in archives can 'out' a composer as a freemason and confirmation of this membership can shed a new light on his intellectual or artistic discourse. It might even offer some insight into the audience this musician was composing for and this in turn might have dictated his musical style, format or language. So, establishing a composer as a

\footnotetext{
${ }^{29}$ Philip Brett, Elizabeth Wood \& Gary C.Thomas eds., Queering the Pitch. The New Gay and Lesbian Musicology (London/New York, 2006).
} 
freemason can have serious repercussions for anyone attempting a serious analysis of his musical style. It could also work the other way around. A study of a composer's style and social network could result in him being labelled a 'possible' or even 'probable' freemason, without having documentary certainty.

In the wider sense, Masonic musicology must address two valuable question, namely: 1) how is a composer's membership to a masonic fraternity relevant to his music? 2) how is the reaction of a masonic audience relevant to a composer's reputation and his music? Some music can be 'experienced' as being 'masonic' in spirit. How does this relate to the composer and his music? In what follows, we want to analyze the relevancies of such claims. In doing so, we will give three examples of how a masonic interpretation can have a huge impact on the understanding of a composer, his work and his culture. In the first example we will talk about a freemason (Mozart) as the author of an established masonic inspired opera (Die Zauberflöte), in the second example we will talk about a composer who was most probably not a freemason (Händel) as the author of an opera with a loose masonic connection (Orlando). Lastly, we will talk about another freemason (Meyerbeer) as the author of an opera with only a very loose masonic connection (Les Huguenots).

Most freemasons today would still consider Mozart's Die Zauberflöte to be a masonic piece. They have good reason to do so, since freemasonry is arguably the most obvious intellectual background of this opera ${ }^{30}$. One could point out that its authors were all freemasons, that Mozart wrote a great deal of other masonic music, one could even call upon many themes in the opera that were being discussed amongst freemasons in Vienna at that time (i.e. Egyptian religion, ancient mysteries, attitudes towards freethinking, etc.) ${ }^{31}$. One could argue that even some contemporaries regarded freemasonry as a key to the opera. Or one could simply point out the parallels between a masonic initiation ritual and the initiation ritual that is being observed in the opera ${ }^{32}$. In the face of this overwhelming evidence, it is difficult to maintain that Freemasonry was of little or no importance at all in the creation of this work.

Some authors do try to debunk the masonic-interpretation-thesis by pointing out that the opera is clearly a fairy tale and not a masonic allegory ${ }^{33}$. But such a claim should address the issue why one interpretation must exclude all others. In other words: why can't it be both? One should remember that New Historians and New Musicologists do not believe there to be one single master discourse. So, from that point of view the argument

\footnotetext{
${ }^{30}$ Jan Assmann, Die Zauberflöte: Oper und Mysterium (München/Wien, 2005), 20.

${ }^{31}$ Helmut Perl, Der Fall “Zauberflöte”. Mozarts Oper im Brennpunkt der Geschichte (Zürich/Mainz, 2000); Assmann, Die Zauberflöte.

32 Jacques Chailly, The Magic Flute Unveiled. Esoteric Symbolism in Mozart's Masonic Opera (Rochester, 1992).

${ }^{33}$ David Buch is the principal disbeliever of the Masonic Thesis. However, his view is a minority view and his attempts to shield the opera from any masonic contextualisation is very deliberate. It takes a conscious effort on his behalf to misread the evidence and draw his conclusions: Buch, "Die Zauberflöte, Masonic Opera and Other Fairy Tales", Acta Musicologica 76 (2004): 193-219. The claim is repeated in Buch, Magic Flutes \& Enchanted Forests. The Supernatural in Eighteenth-Century Musical Theater (Chicago, 2008), 333.
} 
that one interpretation cannot be correct, because another interpretation might make more sense, is nonsense. Mozart's Die Zauberflöte has a clear masonic narrative, but this does not exclude other interpretations. Moreover, freemasons did recognize a masonic connection in this opera, since some German masonic songbooks, like the ones by Höheim (1795) and Mahncke (1798) quickly borrowed or adapted songs from Die Zauberflöte, which shows that this opera was, in Jay MacPherson's words, at least Mason-friendly ${ }^{34}$. So even if, by some strange interpretation, the masonic connection was not made by the authors of the opera, it was soon recognized by its audience.

Considering Händel's Orlando as a masonic piece is a different issue altogether. In his attempt to label this opera as 'masonic' William Gibbons concentrated on the figure of Zoroastro, the sorcerer whose character is clearly modelled after the Persian prophet Zoroaster $^{35}$. In exploring where the character for Händel's opera originated, Gibbons mentions a whole lot of seventeenth and eighteenth century books and plays where a figure like Zoroastro (and with a similar name) is using his supernatural powers to educate and instruct a young pupil in some sort of spiritual or moral quest. Chief amongst those publications is The Travels of Cyrus, published in Paris in 1727 by Andrew Michael Ramsay (1686-1743), better known as the prominent freemason Chevalier Ramsay. Gibbons then explores the success of Ramsay and his publication in London, especially the circle around the Royal Society. Following a strong argument in which he credits Nicola Haym with the authorship over the libretto of Händel's Orlando, he then establishes a connection between Haym and Ramsay, right about the time the libretto is supposed to have been compiled.

Digging deeper, Gibbons then traces the success of the Zoroaster character within masonic circles, arriving at the conclusion that Händel and Haym were capitalising on Ramsay's success by incorporating what seems to have been understood as 'masonic themes' into their opera, ensuring the curiosity about this work amongst freemasons. Indeed, there was no shortage of freemasons amongst Händel's patrons; the Duke of Mantagu and prince Frederick being the most prominent ones. In short, according to Gibbons, Händel and Haym were consciously targeting a masonic audience with Orlando, or at least an audience interested in or curious about freemasonry. This might be one of his article's most significant conclusions. Gibbons then wraps it all up by pointing at some other details and symbols in the opera that would have "made sense" to an English freemason around 1730, adding further weight to the afore mentioned conclusion that this marketing strategy was in fact a conscious move by the authors of the opera.

Readers of this article who wanted to find out whether Händel was a freemason or not, will be disappointed. It is obvious that William Gibbons did not consider it a goal to

\footnotetext{
34 Jay Macpherson, “The Magic Flute and Freemasonry”, University of Toronto Quarterly 76, no. 4 (2007): 1075.

35 William Gibbons, "Divining Zoroastro: Masonic Elements in Händel's Orlando", Eighteenth-Century Life 34, no. 2 (2010): 65-82.
} 
'out' either Händel or Haym as a freemason. Indeed, it is even implied that they were most probably not freemasons. The value of the article transcends this rather dull proposition of 'was he?' or 'wasn't he?'. It rather shows that freemasonry was a cultural force to be reckoned with. At least, Händel and Haym believed their influence to be strong enough to incorporate alleged masonic themes into the opera, hoping that would result in more performances. Gibbon's analyses offer valuable insights into cultural history, masonic history, the reception history of this opera and so on. This is exactly what masonic musicology should be all about.

A very similar case could be made for the opera Zoroastre by Jean-Philippe Rameau and indeed Graham Sadler has tried on more than one occasion to qualify the work as "L'Opéra maçonnique avant Mozart" 36 . Again, whether or not Rameau was a freemason or not is only of secondary importance (he probably wasn't). More important is what themes might have been considered "masonic" by at least some part of the audience. If these themes were indeed recognized as being 'masonic', we can then proceed to find out where they came from and whether or not they were a conscious effort on behalf of the composer or his librettist. The results of this study can therefore be considered a significant contribution to the field French cultural history, halfway the eighteenth century.

In the cases of both Rameau and Händel it is impossible to say whether they were freemasons on the basis of their music alone. Without solid documentary evidence no one should make a claim for any composer (or indeed anyone) to have been a member of the fraternity. The fact that their opera's appealed to freemasons and incorporated some masonic themes or elements does not instantly turn their authors into freemasons. As I have said before, without solid evidence, one can only assign various shades of "greys": from "possibly" to "probably" to "very probably" to "almost certainly".

A totally different line of inquiery must be used when approaching Giacomo Meyerbeer's Grand Opéra Les Huguenots of 1836. Meyerbeer was a German Jew working in Paris who was probably initiated into freemasonry some time during the 1830 s. Just like Mozart, Meyerbeer took the fraternity very seriously and at the time of his death he was Souverain Grand Inspecteur Général and had earned his $33^{\text {rd }}$ degree. Meyerbeer's appears in the records of many Parisian lodges as a membre d'honneur and visited two of them on a regular basis ${ }^{37}$. Just like the typical liberal bourgois politics, liberal freemasonry Grand Opéra, Meyerbeer himself was very much a product of the Orléans-regime (1830-1848) in France.

A serious scholar could attempt to hold Meyerbeer's masterpiece against the political and social culture of his time to see what the role of freemasonry could be in his

\footnotetext{
${ }^{36}$ Sadler, L'Opéra maçonnique avant Mozart, 13-17, and "Zoroastre", New Grove Dictionary of Opera 4, 1244-1246.

${ }^{37}$ Gérard Gefen, "Les Musiciens et la franc-maçonnerie", Fayard (1993) : 152-154. The two lodges he frequented in Paris were: Reconnaissance par les émules d'Hiram and Les Trinosophes.
} 
work $^{38}$. Given the fact that Meyerbeer and his librettist Eugène Scribe, started working on this project around 1831, the opera must be seen against the backdrop of the revolution of $1830^{39}$. The opera about religious violence culminating in the Saint-Bartholomew Massacre of 1572 was a strong statement against the pro-clerical policies under Charles $\mathrm{X}$ and his tendency toward the fusion of state and religion. It was the time where non-catholics were being discriminated against and where sacrilege was being punished by death ${ }^{40}$. This sort of political thinking was swiped away by the revolution of 1830 and his religious politics were certainly a factor of the downfall of Charles X, the last of the Bourbon kings. ${ }^{41}$ Typically themes such as freedom and tolerance are very explicitly promoted within freemasonry, while intolerance, prejudice and irrationality are condemned. This seems to be the case in the opera as well. Would it not be valuable to explore the masonic network around Meyerbeer and to discover what they were talking about during the 1830s? Would it not be valuable to point out in detail the similarities between the message of the opera and the teachings of freemasonry, using examples that must have inspired Meyerbeer himself? Would it not be valuable to study the reactions of freemasons in response to this opera?

\section{What is the value of Masonic musicology?}

Masonic musicology's first concern must be to study the relations between music, its reputation and society. Freemasonry, like any other discourse, cannot help but influence the world around herself. She might have helped in shaping new artistic styles, in spreading new ideas or in stimulating social or political movements. Freemasonry also influenced enough composers for them to write 'masonic music', but masonic musicologists should not limit themselves to the music of Mozart and other well-known composers who were clearly freemasons. As the examples of Händel and Rameau make clear, one can study masonic culture by using their music and still come up with interesting results for other scholars in other fields, whereas a historian who limits himself to a dull in-depth history of his lodge, might not be of similar interest to other scholars. There are many connections to be found by looking at the way in which freemasonry interacted with music. And contributions within masonic musicology might be valuable for historians studying other topics, like nationalism or cultural identity.

Hermine Weigel Williams, for instance, analyzed the masonic music of Jean Sibelius against the background of the Finnish struggle against Russia (1917-1945). Sibelius was initiated in Helsinki in 1924. From the turn of the century onward, Sibelius

\footnotetext{
${ }^{38}$ Unfortunatly such an attempt has not yet been made.

${ }^{39}$ Robert Ignatius Letellier, The Opera's of Giacomo Meyerbeer (Cranbury, 2006), 131-132.

40 Jean-Baptiste Duvergier, Collection complète des Lois, décrèts, ordonnances, réglemens et avis du conseil-d'état, (1925, Tome XXV), 73-76.

${ }^{41}$ Vincent W. Beach, 1825: The Decisive Year of Charles Xs Reign (Boulder Colorado, 1967), 20.
} 
had dared to support events that championed nationalism and freedom for the people of Finland. When writing his masonic music, he was actively participating in a dream that had become reality. Joining freemasonry was just another way to express his love for liberty and his country. It inspired him to rewrite his famous Finlandia for male chorus on a text by his fellow-mason Wäinö Sola, shortly after the Russo-Finnish Winter War of 1939. Although the Finlandia-Hymn was never used for any ritual function for the lodges of Finland, it was sung often enough at the conclusion of masonic meetings and it nearly became the Finnish national anthem at one point ${ }^{42}$.

Therefore, one cannot escape the conclusion that masonic musicology can teach us much about how music participated in shaping notions like nationalism and civil society in eighteenth-nineteenth-and twentieth century culture. Being able to make a 'masonic connection', means we as scholars are given the chance to paint a better picture of the people we study and the art we came to inherit from them. Freemasonry however, is no clear set of values, codes of symbols. Freemasonry, like every other social enterprise, changes and varies over time. Mozart's freemasonry was totally different from that of Sibelius. Freemasonry does not have an essence in that way that every mason who ever lived has the same ideas about it. After all, freemasonry, like art, is a means in which people are trying to make sense of the world around them. This, in turn, means that finding a masonic connection in a study about a work of art, a composer or a network of musicians, is like being offered a window into the ideas that surround this particular piece of art, composer or network. Find out what freemasons were up to and you might be able to get a better understanding of what the music you are studying is all about. It would be a pity if we were to ignore such a line of inquiry simply because the connection with freemasonry might prove to be a subject too sensitive or too tricky to pursue.

\section{Conclusion}

This article holds the position that if the musicologist wants to contribute to the research of the masonic phenomenon, he would profit from following the example of the historian, who has in recent times given up writing detailed histories of individual lodges. Instead, he has tried to attain a deeper understanding of the phenomenon by incorporating into his own methods those of other disciplines. Musicologists and musicians, by nature, have tended to focus on notes, scores, instruments and acoustics and have seldom ventured outside of their own comfort zone. Some of them have done so in the (fairly) recent past: the new musicologists, the queer musicologists and others have tried to find ways to study their topic of choice in relation to music. A masonic musicologist's ambitions should be nothing less.

\footnotetext{
${ }^{42}$ Hermine Weigel Williams, Sibelius and His Masonic Music. Sounds in Silence (Bloomington, 2008), 3 and 84-93.
} 
A masonic musicologist should in no way give up analyzing musical scores. He should however refrain from doing so by trying to "unlock" some sort of musical code, to reveal some hidden symbolism or to count notes and make them fit a preconceived numerological agenda. In such instances, the analyses will refer to little outside the musical score itself and it will be difficult to prove that the codes or symbols one discovers there, exist outside the mind of the discoverer. We all know that freemasons have a reputation of secrecy, of using codes, symbols and rituals, but that does not mean that scholars studying this phenomenon should be encouraged to see symbols or codes everywhere they look, even in musical scores.

A more interesting way of dealing with masonic music, its musicians, its patrons, its performance history, its musical thought, etc. is to focus on the world and the culture that produced it. After all, music can only be said to be meaningful, once it is performed. That is to say: when others have tried to make sense out of it and have in some way responded to it. In studying music in relation to freemasonry, the musicologist should open up the field by trying to build bridges to other areas: the study of rituals, the study of cultural practices, the study of nationalism, etc. - all examples that have led to concrete and sometimes even fascinating results. This means skimming through the theoretical literature of ethnomusicology, cultural anthropology, civil society, etc., looking for inspiration. Finding out how masonic music "works" or how masonic themes can resonate through music or why they were important to either the author(s) or (a small part of) his public can shed new light on our understanding of freemasonry in particular or cultural history in general. Only then will the work of the masonic musicologist be more likely to be taken into account by others and be deemed relevant.

\section{Bibliography}

Alexander, Jeffrey. "Cultural Pragmatics: Social Performance between Ritual and Strategy”. Sociological Theory 22, no. 4 (2004): 527-573.

Alexander, Jeffrey and Philp Smith. "Introduction: The Rise and Fall and Rise of Clifford Geertz". In Interpreting Clifford Geertz. Cultural Investigation in the Social Sciences. Edited by Jeffrey Alexander, Philip Smith \& Matthew Norton. New York, 2011.

Alexander, Jeffrey ed. The Meaning of Social Life: A Cultural Sociology. Oxford: Oxford University Press, 2003.

Assmann, Jan. Die Zauberflöte: Oper und Mysterium. München/Wien, 2005.

Barthes, Roland. Mythologies trans. A. Lavers. New York, 1972.

Beach, Vincent W. 1825: The Decisive Year of Charles Xs Reign. Boulder Colorado, 1967. 
Bogdan, Henrik. "The Sociology of the Construct of Tradition and Import of Legitimacy in Freemasonry". In Constructing Tradition: Means and Myths of Transmission in Western Esotericism. Edited by Andreas Kilcher. Leiden/Boston: Brill, 2010.

Bogdan, Henrik. Western Esotericism and Rituals of Initiation. New York, 2007.

Brett, Philip, Elizabeth Wood y Gary Thomas eds. Queering the Pitch. The New Gay and Lesbian Musicology. London/New York, 2006.

Buch, David. "Die Zauberflöte, Masonic Opera and Other Fairy Tales". Acta Musicologica 76 (2004): 193-219.

Buch, David. Magic Flutes \& Enchanted Forests. The Supernatural in Eighteenth-Century Musical Theater. Chicago, 2008.

Chailly, Jacques. The Magic Flute Unveiled. Esoteric Symbolism in Mozart's Masonic Opera. Rochester, 1992.

Chambers, Ross. Story and Situation: Narrative Seduction and the Power of Fiction. Minneapolis, 1984.

Coy, Jean-Louis. Forces Occultes. Le complet judéo-maçonnique au cinéma. Paris, 2008.

Duda, Johannes, Gunther Kerner and Dieter Dalchow. W.A. Mozart - Die Dokumentation seines Todes. Pähl/Obb: von Bebenburg, 1966.

Duvergier, Jean-Baptiste. Collection complète des Lois, décrèts, ordonnances, réglemens et avis du conseil-d'état (1925, Tome XXV).

Geertz, Clifford. The Interpretation of Cultures. New York, 1973.

Geertz, Clifford. "Passage and Accident: A Life of Learning". In Available Lights: Anthropological Reflections on Philosophical Topics. Princeton, 2000.

Gefen, Gérard. "Les Musiciens et la franc-maçonnerie". Fayard (1993): 152-154.

Gibbons, William. "Divining Zoroastro: Masonic Elements in Händel's Orlando". Eighteenth-Century Life 34, no. 2 (2010): 65-82.

Greenblatt, Stephen. Shakespearean Negotiations: The Circulation of Social Energy in Renaissance England. Berkeley, 1988.

Greenblatt, Stephen ed. "The Forms of Power and the Power of Forms in the Renaissance". Genre $N^{\circ} 15$ (1982), introduction.

Hermann, Alf. Geheimes_Louisenlund. Einblicke in Europa's Bedeutendsten Freimaurerpark. Kiel, 2010.

Hermanowicz, Joseph C. and Harriet P. Morgan. "Ritualizing the Routine: Collective Identity Affirmation”. Sociological Forum 14, no. 2 (1999): 197-214.

Houben, Jan. "The Ritual Pragmatics of a Vedic Hymn: The «Riddle Hymn» and the Pravargya Ritual”. Journal of the American Oriental Society 120, no. 4 (2000): 499536.

Howard, Jean. "The New Historicism in Renaissance Studies". In: New Historicism and Renaissance Drama. Edited by Richard Wilson \& Richard Dutton. London/New York, 1992. 
Jameson, Fredric. The Political Unconscious: Narrative as a Socially Symbolic Act. Ithaca, 1981.

Kreinath, Jens, Jan Snoek and Michael Stausberg. Theorizing Rituals: Issues, Topics, Approaches, Concepts. Leiden/Boston: Brill, 2007.

Kuhn, Thomas S. The Structure of Scientific Revoutions. Chicago, 1962.

Kunst, Jaap. Musicologica: A Study of the Nature of Ethnomusicology, Its Problems, Methods and Representative Personalities. Amsterdam, 1950.

Letellier, Robert Ignatius. The Opera's of Giacomo Meyerbeer. Cranbury, 2006.

Loir, Christophe and Jacques Lemaire. Franc-Maçonnerie et Beaux-Arts. Bruxelles, 2007.

Macpherson, Jay. "The Magic Flute and Freemasonry". University of Toronto Quarterly 76, no. 4 (2007).

McClary, Susan. Conventional Wisdom. The Content of Musical Form. Berkeley/London, 2000.

Nettl, Bruno. "Mozart and the Ethnomusicological Study of Western Culture: An Essay in Four Movements". In Desciplining Music: Musicology and its Canon. Edited by Katherine Bergeron and Philip V. Bohlman. Chicago, 1992.

Nettle, Paul. Mozart and Masonry. New York: Philosophical Library, 1957.

Perl, Helmut. Der Fall "Zauberflöte”. Mozarts Oper im Brennpunkt der Geschichte. Zürich/Mainz, 2000.

Pieters, Jürgen. Moments of Negotiation. The New Historicism of Stephen Greenblatt. Amsterdam, 2001.

Rappopor, Dana. "Ritual Music and Christianization in the Toraja Highlands, Sulawesi". Ethnomusicology 48 (2004): 378-404.

Reinalter, Helmut. Freimaurerische Kunst - Kunst der Freimaurerei. Innsbruck: 2005.

Robbins-Landon, H.C. 1791: Mozart's Last Year. New York: Thames and Hudson, 1988.

Sadler, Graham. L'Opéra maçonnique avant Mozart: Le Zoroastre de Rameau, sleeve notes to the 2001 Erato-recording by William Christie and Les Arts Florissants, 13-17.

Sadler, Graham. "Zoroastre”. New Grove Dictionary of Opera 4, 1244-1246.

Silverman, Kaja. "The Dominant Fictions. In Male Subjectivity at the Margins. Edited by Kaja Silverman. New York, 1992.

Snoek, Jan. Initiating Women in Freemasonry: The Adoption Rite. Leiden: Brill, 2011.

Snoek, Jan. Initiations. A methodological approach to the Application of Classification and Definition Theory in the Study of Rituals. Pijnacker, 1987.

Snoek, Jan, Monika Scholl, and Andréa Kroon. Symbolik in Gärten des 18. Jahrhunderts. Der Einfluss unterschiedlicher philosophischer Strömungen, wie auch der Freimaurerei. Den Haag, 2006.

Stevens Curl, James. The Art \& Architecture of Freemasonry. New York, 1999. 
Tyssens, Jeffrey. "A Lodge of Sorrow for King Leopold I of Belgium (1866): Masonic Patriotism and Spirituality on Trial". Journal for Research into Freemasonry and Fraternalism 3, no. 2 (2012): 248-264.

Tyssens, Jeffrey. In Vrijheid Verbonden. Studies over Belgische Vrijmetselaars en hun Maatschappijproject in de 19de eeuw. Gent, 2009.

Tyssens, Jeffrey ed. Schatten Van De Tempel. Mercatorfonds, 2006.

Van Den Berk, M.F.M. The Magic Flute: Die Zauberflöte: An Alchemical Allegory. Leiden: Brill, 2004.

Vergauwen. David. “'Aux Mânes d'un F[rère] qui fut Roi': a Cantata by K.L. Hanssens On the Death of King Leopold I of the Belgians". Journal for Research into Freemasonry and Fraternalism 3, no. 2 (2012): 265-287.

Vergauwen, David. Kolommen van Harmonie. Muziek en Vrijmetselarij in het Brussel van de Negentiende Eeuw. Brussel: ASP, 2015.

Vergauwen, David. "Wagner und die Freimaurer - Die Wagner-Mode in Brüssel (18701900)". Wagnerspectrum 2 (2012): 201-210.

Wegener, Franz. Der Freimaurergarten. Norderstedt, 2008.

Weigel Williams, Hermine. Sibelius and His Masonic Music. Sounds in Silence. Bloomington, 2008.

Williams, Raymond. Marxism and Literature. Oxford, 1977.

Wong, Deborah. "Mon Music for Thai Deaths: Ethnicity and Status in Thai Urban Funerals". Asian Folklore Studies 57, no. 1 (1998): 99-130. 